\title{
RECENT RESEARCH AND APPLICATIONS OF SEISMIC ISOLATION IN NEW ZEALAND

\author{
W.H. Robinson' 1
}

\begin{abstract}
In New Zealand, seismic isolation, the technique in which the structure is decoupled from earthquake-induced ground motions, has now advanced to the point where it is often considered for the protection of both new and existing buildings, bridges, and to a lesser extent, industrial plant.

Many of the devices used in these applications have been developed in our laboratory. We describe here how the lead-based devices operate, and we give some examples of the application of seismic isolation to structures in New Zealand.

Current interest is focused on the application of seismic isolation to three buildings in central Wellington. In July 1993, the construction of the seismically isolated Museum of New Zealand was started on the Wellington waterfront. All of the lead-rubber isolators have now been tested and installed. Nearby the NZ Parliament Building and Library have been retrofitted with a lead-rubber bearing system.

To support the continuation of improvements to the seismic resistance of structures a number of research programs are operating in the Universities of Auckland and Canterbury, the Engineering Seismology Section of the NZ Institute of Geological and Nuclear Sciences, Works, a number of engineering consultants and in our company.

Very strong support for the principles of seismic isolation is given by the fact that of the ten hospitals affected by the 1994 Northridge earthquake in Los Angeles, only the hospital seismically isolated by a lead-rubber bearing system was able to continue to operate. Further support is given by the excellent behaviour of two isolated buildings in the 1995 Hyogo Ken-Nanbu earthquake).
\end{abstract}

\section{INTRODUCTION}

Seismic isolation is a technique in which a structure is decoupled from earthquake induced ground motions. In Italy, USA, Japan and New Zealand this technique has now advanced to the point where it is often considered for the protection of both new and existing buildings, bridges, and to a lesser extent, industrial plant. The use of seismic isolation in China has been supported with the opening in May 1994, of the seismically isolated demonstration building in Shantou City. In this project, supported by UNIDO, the building is mounted on high damping rubber bearings.

Our studies of seismic isolation began in 1968 as the synthesis of two groups working in the fields of Materials Science and Engineering Seismology respectively. This research has had three main components: experiments, theoretical work and the application of seismic isolation devices. The work has been described in the book "An Introduction to Seismic Isolation" by Skinner, Robinson and McVerry [1993] whose final chapter describes the use of seismic isolation in buildings and bridges world-wide. Table 1 summarises these applications in Italy, Japan, USA and New Zealand, up to 1994.

\footnotetext{
${ }^{1}$ Penguin Engineering Ltd, Petone, New Zealand
}

(Fellow)
Very strong support for the principles of seismic isolation is given by the fact that of the ten hospitals affected by the 1994 Northridge earthquake in Los Angeles, only the hospital seismically isolated by a lead-rubber bearing system was able to continue to operate. This seven-storey hospital, the University of Southern California Teaching Hospital, underwent ground accelerations of $0.49 \mathrm{~g}$, with $0.38 \mathrm{~g}$ under the building, while the rooftop acceleration was $0.21 \mathrm{~g}$, that is an attenuation by a factor of 1.8. The Olive View Hospital, nearer to the epicentre of the earthquake, underwent a top floor acceleration of $2.31 \mathrm{~g}$ compared with its base acceleration of $0.82 \mathrm{~g}$, a magnification by a factor of 2.8. The Olive View Hospital, designed to strength criteria suffered no structural damage but had to be closed temporarily because the high acceleration caused a water pipe to burst on the top floor. Within $1 \mathrm{~km}$ of the University Teaching Hospital, the Los Angeles County Hospital suffered severe damage causing the closure of a number of wings. Repair of this damage is estimated to cost US $\$ 400$ million.

In the January 1995 Hyogo Ken-Nanbu earthquake, a building in Kobe isolated with a lead-rubber bearing systems in the affected zone survived with no damage. For this building, the Computer Centre of the Ministry of Post and Telecommunications, preliminary results indicate a maximum ground acceleration of $0.40 \mathrm{~g}$ while the sixth floor acceleration had a maximum of $0.13 \mathrm{~g}$, that is an attenuation by a factor of 
Table 1: Applications of Seismic Isolation Devices in New Zealand, Japan, USA and Italy

\begin{tabular}{|c|c|c|}
\hline Year/Country & Structure(s) & Damping System(s) \\
\hline \multicolumn{3}{|l|}{1974 to $1985:$} \\
\hline New Zealand & bridges & $\begin{array}{l}19 \text { LRB, } 2 \text { LED, } 4 \\
\text { Steel }\end{array}$ \\
\hline $\begin{array}{l}\text { Japan } \\
\text { Italy }\end{array}$ & $\begin{array}{l}\text { buildings } \\
\text { buildings } \\
\text { bridges }\end{array}$ & $\begin{array}{l}1 \text { LRB, } 1 \text { Steel } \\
1 \text { Friction } \\
19 \text { Elastomeric, } 9 \\
\text { Viscous }\end{array}$ \\
\hline \multicolumn{3}{|l|}{1985 to $1995:$} \\
\hline \multirow[t]{2}{*}{ New Zealand } & bridges & $\begin{array}{l}21 \mathrm{LRB}, 1 \mathrm{LRB}+\mathrm{LED} \text {, } \\
3 \text { Steel }\end{array}$ \\
\hline & buildings & $1 \mathrm{LED}, 4 \mathrm{LRB}$ \\
\hline \multirow[t]{2}{*}{ Japan } & buildings & $\begin{array}{l}21 \text { LRB, } 17 \text { Steel, } 7 \\
\text { Friction, } 5 \text { Viscous, } 9 \\
\text { Elastomeric }\end{array}$ \\
\hline & bridges & 19 LRB, 4 Elastomeric \\
\hline \multirow[t]{2}{*}{ USA } & buildings & $\begin{array}{l}9 \text { LRB, } 2 \text { Friction, } 5 \\
\text { Elastomeric }\end{array}$ \\
\hline & bridges & $81 \mathrm{LRB}$ \\
\hline \multirow[t]{2}{*}{ Italy } & bridges & $\begin{array}{l}6 \text { LRB, } 75 \text { Steel, } \\
29 \text { Viscous, } \\
14 \text { Elastomeric }\end{array}$ \\
\hline & buildings & 4 Elastomeric \\
\hline
\end{tabular}

Key: $\quad$ LRB $=$ Lead rubber bearing; LED $=$ Lead extrusion damper: Steel includes cantilevers, beams, etc undergoing plastic deformation: Elastomeric includes Rubber and Neoprene bearings. High damping rubber bearings plus other elastomers; Friction includes PTFE sliding bearings plus other sliding supports.
3.1. At the time of the earthquake the Computer Centre, with a floor area of $46,823 \mathrm{~m}^{2}$ was the largest seismically isolated building in the world.

\section{FLEXIBILITY AND DAMPING}

Seismic isolation systems have two important functions:

- The period of the isolated structure is increased to a value beyond that which dominates in a typical earthquake

- The displacement is controlled (to $100-400 \mathrm{~mm}$ ) by the addition of an appropriate amount of damping (usually 5 to 15 percent of critical).

The increased period ( $>1.5$ seconds, usually 2 to 3 seconds) is achieved via a flexible support which provides a reduction in the 'stiffness' or 'spring constant' between the structure and the ground. Examples include flexible piles and rubber elastomeric bearings. The damping is usually hysteretic, provided by plastic deformation of either steel or lead or by 'viscous' damping of high-damping rubber. For these dampers strain amplitudes, in shear, often exceed 100 percent. The high damping has the effect of reducing the displacement by a factor of up to five from unmanageable values of $\sim 1$ metre to large but reasonable sizes of $<300 \mathrm{~mm}$.

Figure 1 shows the principle underlying seismic isolation. There is a 'trade-off' between decreased acceleration and increased displacement when a system is seismically isolated. The effect of damping for controlling displacement is also shown, with increased damping reducing the displacement.

Table 2 groups common devices according to whether they are linear or nonlinear. A system which has linear damping and linear elastic restoring force will give rise to a forcedisplacement hysteresis loop as shown in the inner loop of Figure 3(b), while a characteristic nonlinear system is illustrated by the outer loops.
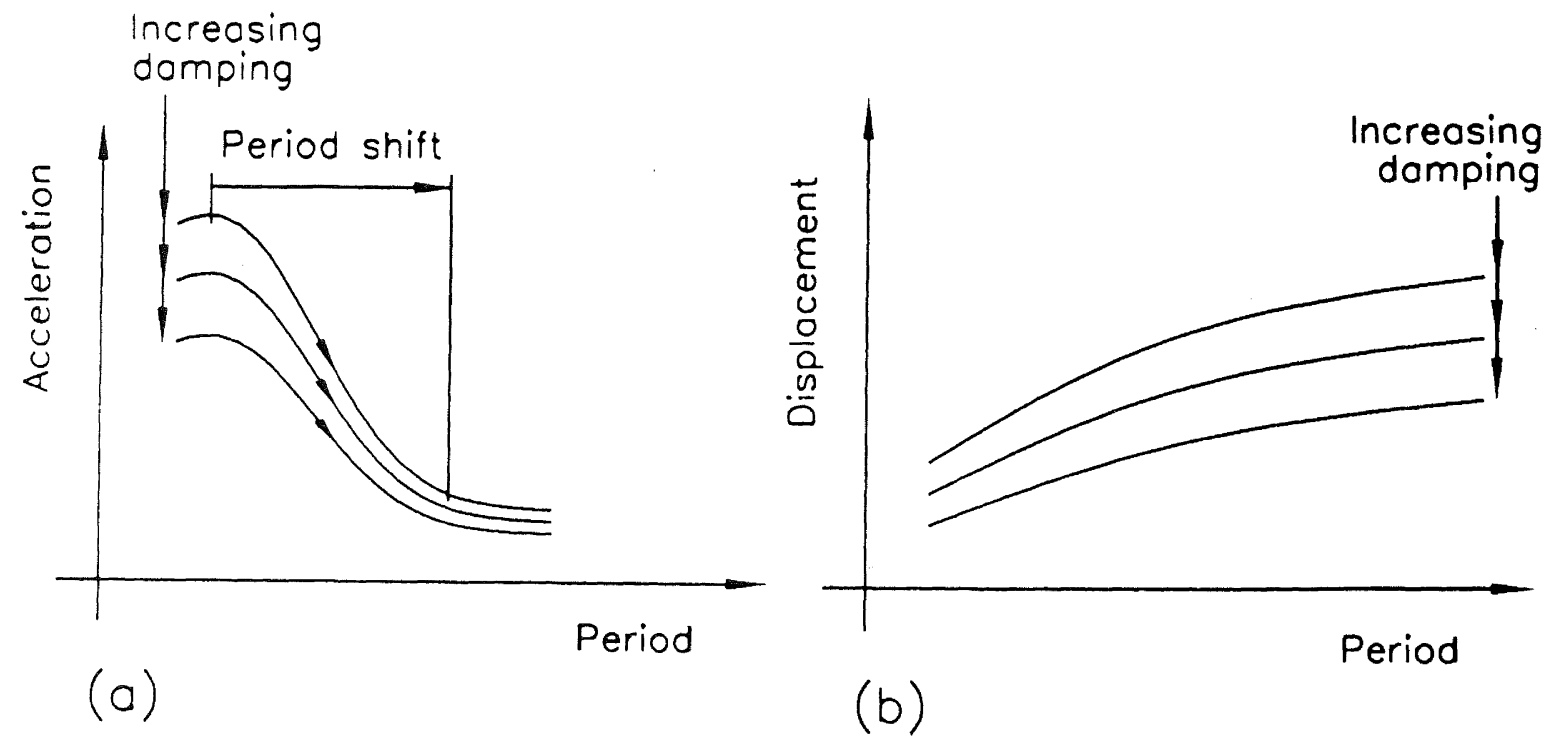

FIGURE 1 Effect of period and damping on (a) acceleration and (b) total displacement for the isolated system 
Table 2: Flexibility and damping of common seismic isolators

\begin{tabular}{|c|c|c|}
\hline Property & Linear & Nonlinear \\
\hline $\begin{array}{l}\text { Restoring Force- } \\
> \\
\text { (providing spring } \\
\text { constant and } \\
\text { flexibility) }\end{array}$ & $\begin{array}{l}\text { *Laminated } \\
\text { bearings } \\
\text { *Flexible piles or } \\
\text { columns } \\
\text { *Springs } \\
\text { *Spheres between } \\
\text { curved surfaces } \\
\text { (gravity) }\end{array}$ & $\begin{array}{l}\text { *High-damping } \\
\text { rubber bearings } \\
\text { *Lead-rubber } \\
\text { bearings } \\
\text { *Buffers } \\
\text { *Stepping } \\
\text { (gravity) }\end{array}$ \\
\hline Damping ----> & $\begin{array}{l}* \text { Laminated rubber } \\
\text { bearings } \\
* \text { Viscous dampers }\end{array}$ & $\begin{array}{l}\text { *High-damping } \\
\text { rubber bearings } \\
\text { *Lead-rubber } \\
\text { bearings } \\
\text { *Lead extrusion } \\
\text { dampers } \\
\text { *Steel dampers } \\
\text { *Friction (eg } \\
\text { PTFE) }\end{array}$ \\
\hline
\end{tabular}

\section{DEVICES BASED ON THE PLASTICITY OF LEAD}

High-damping hysteretic devices which rely on the plastic deformation of steel or lead have many engineering and industrial applications, such as the seismic isolation of buildings, bridges and delicate or hazardous equipment. Another use is in the control of vibration such as in the 'rail' of the magnetically levitated train at present undergoing tests in Japan.

Devices invented and developed in our laboratory, and successfully applied in real seismic isolation systems, include various designs of steel damper, the lead-extrusion damper and the lead-rubber bearing. It is the lead devices which have received most application in New Zealand.

The lead extrusion damper in which lead is cyclicly extruded is in the form of two versions; the 'constricted tube' and the 'bulged shaft' types. The 'constricted tube' type consists essentially of two pistons on a shaft which forces lead through a constriction (Figure 2(a)). The 'bulged shaft' extrusion damper, in which a bulged shaft is pushed through a cylinder of lead, is easier to manufacture in practice. In both types of device the process of recovery of mechanical properties after and during plastic deformation is rapid (ca. 1ms) via the interrelated processes of recovery, recrystallisation and grain growth. These processes are particularly efficient at ambient temperatures because of the low melting point of lead $\left(327^{\circ} \mathrm{C}\right)$. The almost rectangular elastic-plastic force-displacement hysteresis loop typical of such dampers is shown in Figure 2(b).
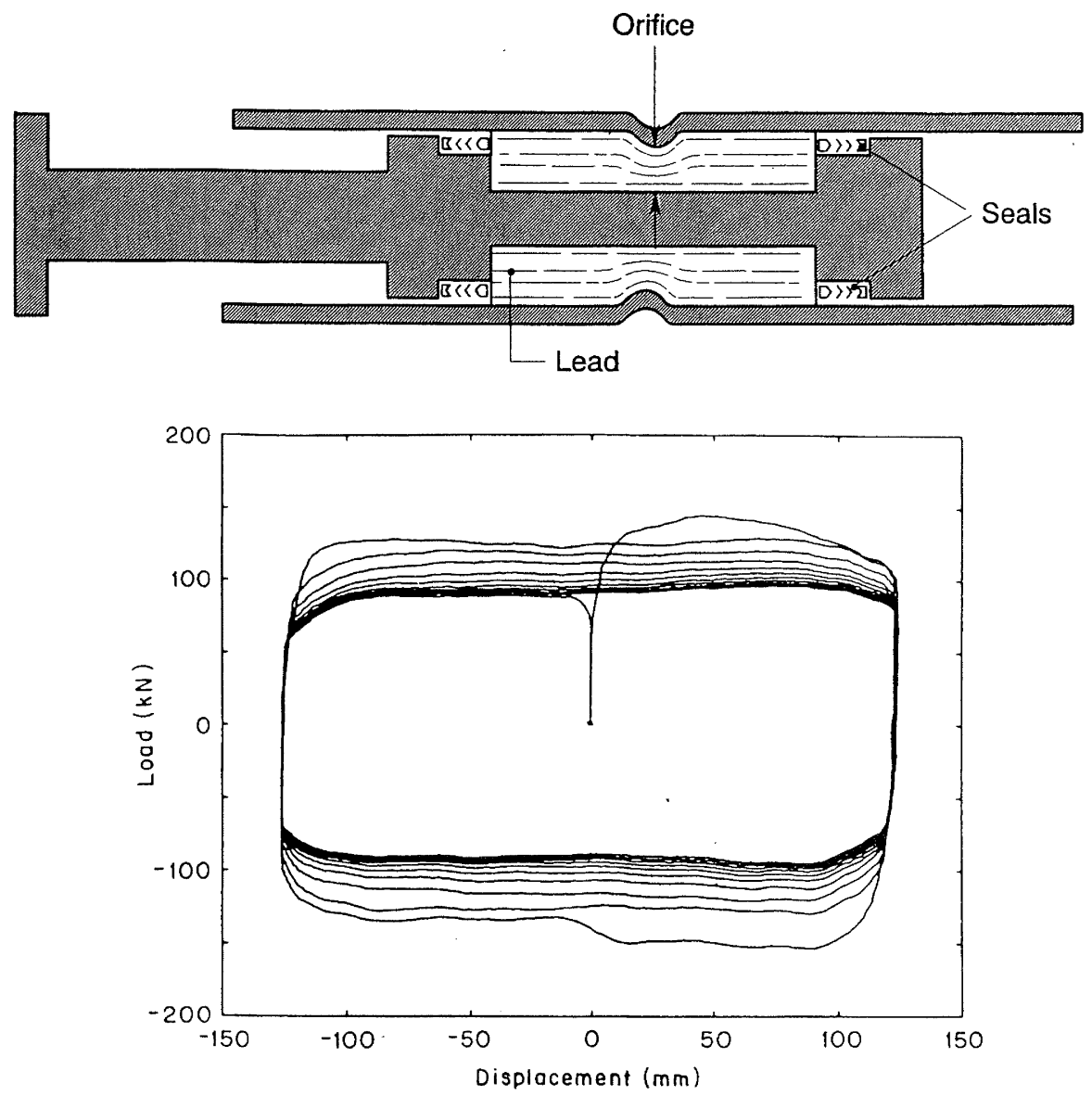

FIGURE 2 (top) Schematic of 'constricted tube' lead extrusion damper; (bottom) forcedisplacement loop for lead extrusion damper 
The lead-rubber bearing consists essentially of a lead insert inside a laminated elastomeric bearing of the type commonly used in bridges to accommodate thermal expansion. In a similar way to the lead in the extrusion damper after plastic deformation of the lead in the lead-rubber bearing it rapidly undergoes the interrelated processes of recovery, recrystallization and grain growth. Figure 3(a) shows schematically a typical lead-rubber bearing and Figure 3(b) is a superposition of hysteresis loops obtained when testing the bearings manufactured by DIS Pacific Limited for the NZ Parliament Building described below. For these tests the axial load was 1.6 MN (160 tonnes) and a cycling rate of $0.1 \mathrm{~Hz}$. The inside loops are for a high-damping rubber bearing while the outside loops are for a lead-rubber bearing.

Figure 3(b) can be understood as follows: It has been found that to a good approximation the total force required to shear a lead-rubber bearing, $F(L R B)$, is given by

$$
\mathrm{F}(\text { rubber })+\mathrm{F}(\text { lead })=\mathrm{F}(\mathrm{LRB})
$$

where $F$ (rubber) and $F$ (lead) are the forces required to shear the rubber and lead respectively as shown in Figure 4.

The damping parameter, $\mathrm{h}$, defined as the energy absorbed in one cycle, $\Delta \mathrm{W}$, divided by $2 \pi$ times the maximum elastic energy, $k(r) x^{2}(\max ) / 2$, where $k(r)$ is the elastic shear stiffness of the bearing. Thus for the lead-rubber bearing:

$$
\mathrm{h}=\Delta \mathrm{W} / \pi\left(\mathrm{k}(\mathrm{r}) \mathrm{x}^{2}(\max )\right)
$$

\section{THE WELLINGTON CENTRAL POLICE STATION}

The Wellington Central Police Station, completed in 1990, is isolated by mounting the building on twenty four flexible piles $15 \mathrm{~m}$ long giving a calculated period of -3 seconds and twenty four lead extrusion dampers providing the required damping [Charleson et al, 1987]. The dampers operate at a force of 250 $\mathrm{kN}$ and have a maximum stroke of $\pm 400 \mathrm{~mm}$. Note in Figure 5 the diagonal bracing which enables the building to move as a rigid body. In dealing with the builders, owners and occupiers of this structure we have emphasised the importance of maintaining the security of the seismic gap which is vital to the operation of any isolation system during an earthquake.

The design and construction of this building presented an interesting challenge in that the site, on reclaimed land, is near the Wellington fault and the building has an important Civil Emergency role.

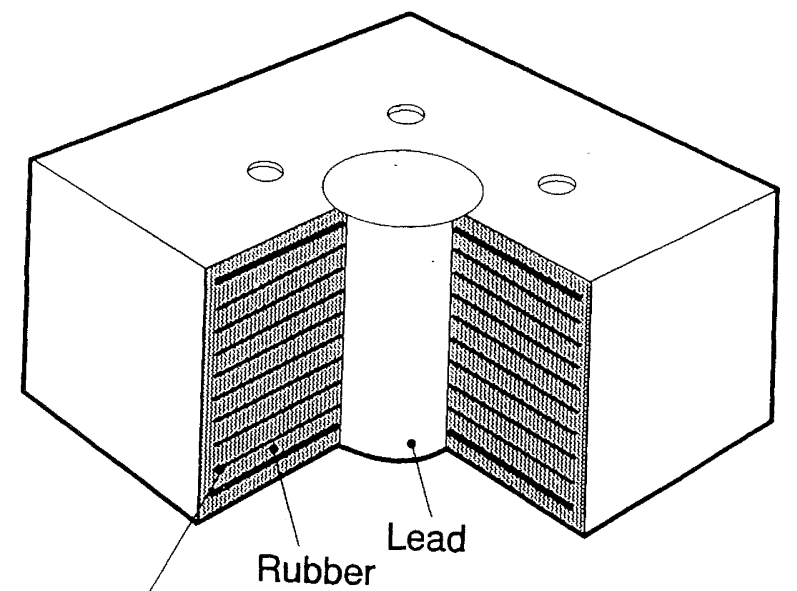

Steel lamination

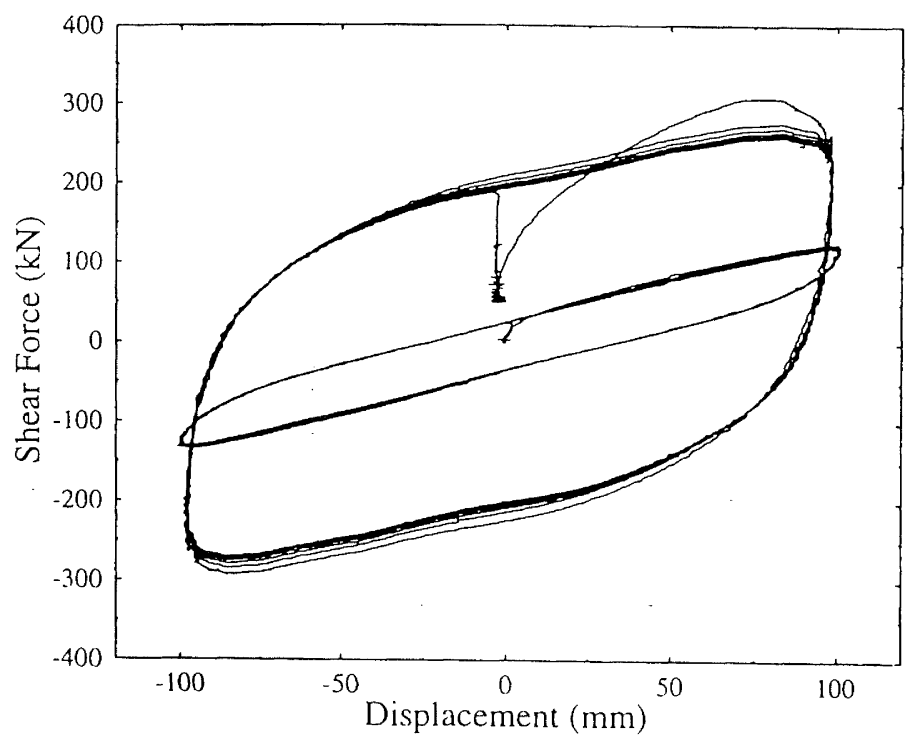

FIGURE 3 (top) Schematic diagram showing the laminated layers of rubber and steel together with the lead insert; (bottom) hysteresis loops for high-damping rubber bearing (inside loops) and lead-rubber bearings (outside loops)

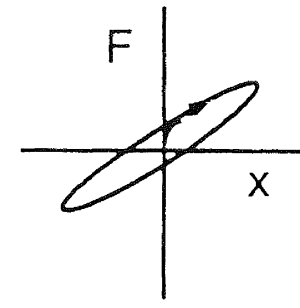

(a)

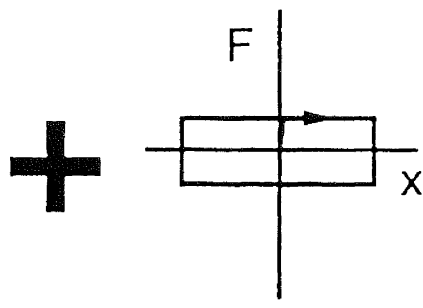

(b)

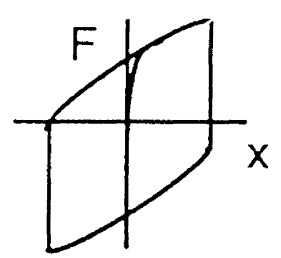

(c)

FIGURE 4 Force-displacement hysteresis loops for (a) linear damped elastic material such as rubber, (b) plastic material such as lead and (c) lead-rubber bearing 


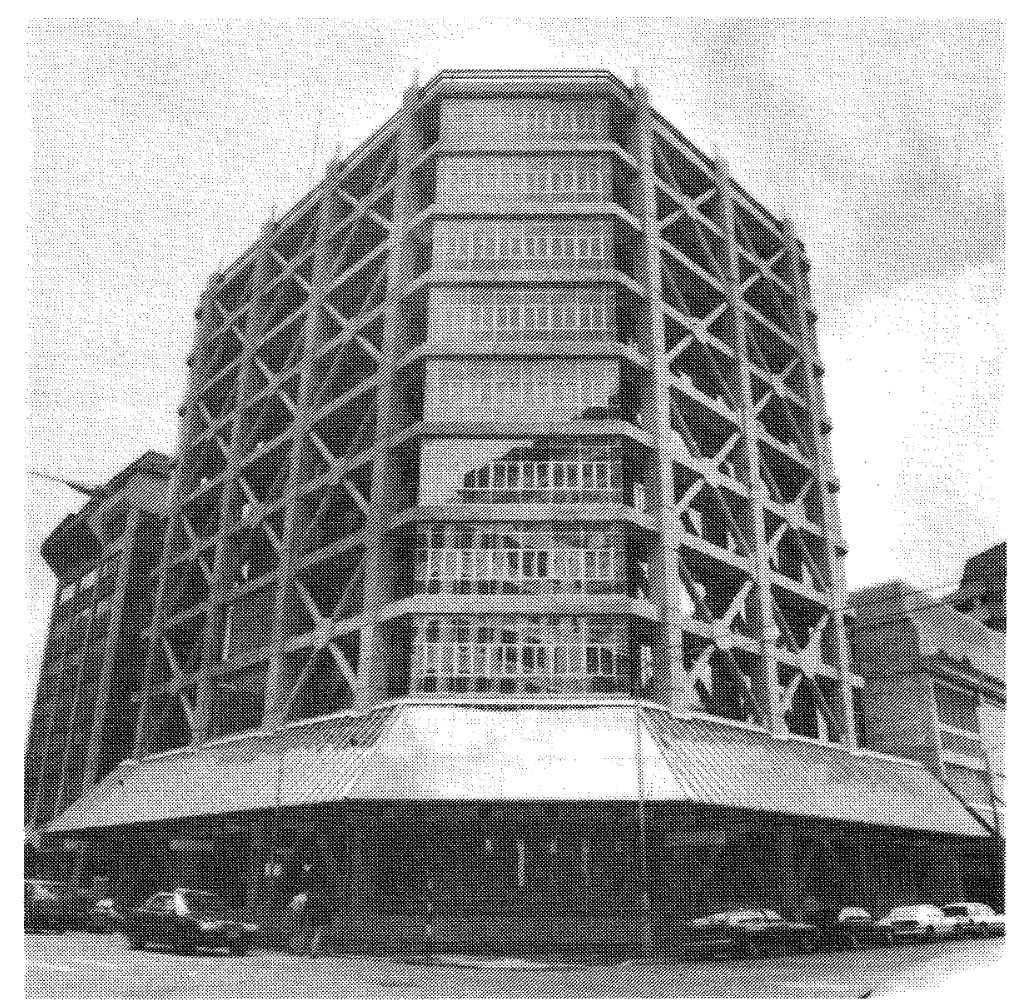

FIGURE 5 Wellington Central Police Station

The police station facilities were required to remain functional after a major earthquake i.e. after a 450 -year return period event which had shaking equivalent to $1.4 \mathrm{x}$ El Centro (NS) $1940,3.2 \mathrm{x}$ Taft (S69E) 1952, PGA $=0.60 \mathrm{~g}$, and $0.64 \mathrm{x}$ Pacoima (S14W) 1971.The earthquake records used in the analyses were scaled to match the design spectra at the fundamental period of vibration, namely $3.0 \mathrm{~s}$.

The police station has a 10 storey tower block above a separate basement (Figure 5). The tower block was isolated by supporting it on pin-ended piles separated from the ground by hollow sleeves, with horizontal displacement control in the form of lead extrusion dampers (Figure 2) located at ground level and pinned between the base of the tower block and the basement. The reinforced concrete superstructure was stiffened by diagonal bracing. A detailed description of the isolation system and the structure has been given by Charleson et al [1987], who noted that there was a saving of $10 \%$ in the structural cost associated with the seismic isolation option.

The calculated maximum horizontal displacement of the ground floor in the 1000-year return period excitations was $\pm 355 \mathrm{~mm}$. Such a large displacement demand, together with the almost elasto-plastic response required from the energy dissipators, led to the choice of lead-extrusion dampers. Six dampers, each rated at $250 \mathrm{kN}$ force and $\pm 400 \mathrm{~mm}$ stroke, were mounted along each side of the tower block, so as to give a total damping force of $3 \mathrm{MN}$, or $3.5 \%$ of the building's seismic weight, in each orthogonal direction.

Because the $250 \mathrm{kN}$ damper was nearly twice as large as any previously manufactured, an extensive mechanical testing program was carried out. All manufactured dampers were subjected to 6 cycles of $\pm 250 \mathrm{~mm}$ displacement at $0.1 \mathrm{~Hz}$ at ambient temperature and one, a prototype, was similarly cycled at a temperature of $0^{\circ} \mathrm{C}$. The hysteretic behaviour of the 250 $\mathrm{kN}$ damper (Figure 2(b)) was satisfactory and similar to that of the smaller dampers previously tested [Robinson and Greenbank, 1976; Robinson and Cousins, 1988]. Apart from minor perturbations caused by the segmented nature of the lead core, the load remained steady between changes in the direction of displacement, and there was a continuing decrease in load and energy absorption with cycling as the lead in the damper was heated.

\section{BRIDGES}

The first bridge to be seismically isolated in New Zealand was the Motu Bridge, in 1973, which used steel in flexure for damping. Since 1973 a total of 49 road and rail bridges in New Zealand have been seismically isolated, eight being retrofitted (Table 1).

Since its invention in 1976 by far the most common system for seismically isolating bridges in NZ, Japan and USA has been the lead-rubber bearing. Usually the lead-rubber bearings are installed between the bridge superstructure and the supporting piers. One of the reasons for the popularity of this mode of seismic isolation is the fact that it combines the functions of isolation and energy dissipation in a single compact unit, whilst supporting the weight of the superstructure and providing an inelastic restoring force. 
The lead plug in the centre of the elasiomeric bearing is subject to shear deformation under horizontal loading, providing considerable energy dissipation when it yields under severe earthquake loading. The lead-rubber hearing provides an extremely economic solution for seismically isolating bridges.

Of the buildings and bridges seismically isolated in New Zealand to date. only one, the Te Teko Bridge over the Rangitaiki River, has undergone the effects of a large earthquake (the Edgecumbe earthquake in March 1987. Richter magnitude 6.3. MM9). However. one of the elastomeric hearings elsewhere on the bridge was not properly restrained against sliding. and was thrown out of position, so that it ceased supporting the deck. The behaviour of the bridge was, therefore, not perfect.

\subsection{Bannockburn Bridge}

The Bannockburn Bridge (completed 1988) is a particularly interesting example in which the forces on the piles are controlled by having the more flexible lead-rubber bearings berween the bridge deck and the piles. while the main damping force is provided by the lead-extrusion dampers and the leadrubber bearings at the abutments (Figure 6).

\section{RETROFIT OF SEISMIC ISOLATION IN TWO HISTORIC BUILDINGS}

The first building in the world to be seismically isolated with lead-rubber bearings was the William Clayton Building in Wellington (completed 1981). For this building, sitting on 80 lead-rubber bearings. the natural period of the isolated building was estimated at 2.5 seconds with a yield force to seismic weight ratio of $-5 \%$. Several other new buildings have been isolated in this way in New Zealand, but the retrofit of seismic isolation to existing buildings in New Zealand has only just begun.

The retrofitting of seismic isolation in two seismically vulnerable masonry buildings of historic significance, namely the old Parliament Building and the Parliament Library in central Wellington. is now under way. All of the 514 bearings for the lead-rubber seismic isolation system have been tested in our laboratory. and they have been installed by the contractors. The various associated engineering works, such as refurbishment, are near completion.
The retrofit involves re-piling the building with lead-rubber bearings and rubber bearings in the supports, as well as cutting a seismic gap in the $500 \mathrm{~mm}$ thick concrete walls. During an earthquake the building will be able to move in any direction on a horizontal plane up to distances of $300 \mathrm{~mm}$. Figure 7 shows the new foundations and beams being installed under the floor and also shows a lead-rubber bearing at the top right of the photograph.

The effect of the isolation is calculated as increasing the fundamental period from a value of 0.45 seconds to 2.5 seconds [Poole and Clendon, 1992].

A diagram of a lead-rubber bearing is shown in Figure 3(a) while Figure 3(b) contains the force-displacement curves for the high damper rubber bearing (inner loop) and the lead-rubber (outer loop) bearings manufactured by DIS Pacific Ltd for the NZ Parliamentary Buildings. These results were obtained with an axial load of 1.6 MN (160 tonnes) and a cycle rate of 0.1 $\mathrm{Hz}$.

The hysteresis loops shown in Figure 3(b) were obtained during tests on these bearings. All 514 bearings retrofitted to these two buildings perform within $\pm 5 \%$ of the specifications as part of the total quality management.

\section{SEISMIC ISOLATION OF THE MUSEUM OF NEW ZEALAND}

The construction of a major new building, the Museum of New Zealand, on the waterfront in central Wellington, started in June 1993. This $190 \times 104 \mathrm{~m}$ building with a triangular floor plan is being isolated by 142 lead-rubber bearings with teflon sliding bearings under the shear walls (see Figure 8(a)). The museum with five floor levels has a total floor area of 35,000 square metres and height of 23 metres.

The building was not designed to a code but instead is required to suffer no damage in a 250 year return period earthquake and not collapse with a 2000 year earthquake [Tyler, 1978]. The calculated maximum floor accelerations for the 250 year earthquake, for the fixed-base and isolated cases, are 1.02 and $0.33 \mathrm{~g}$ respectively. For the 2000 year event these values rise to 1.69 and $0.48 \mathrm{~g}$ clearly illustrating the advantages of seismic isolation.

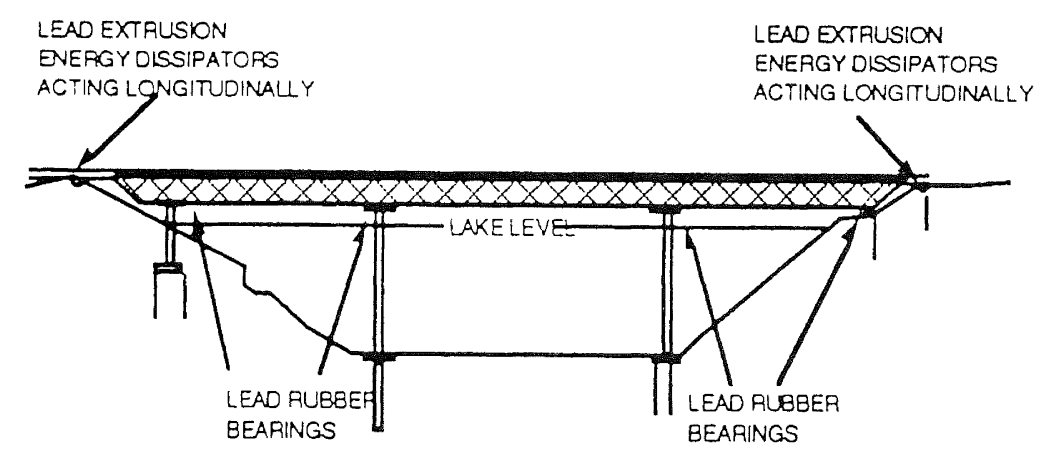

$150 \mathrm{~m}$ 


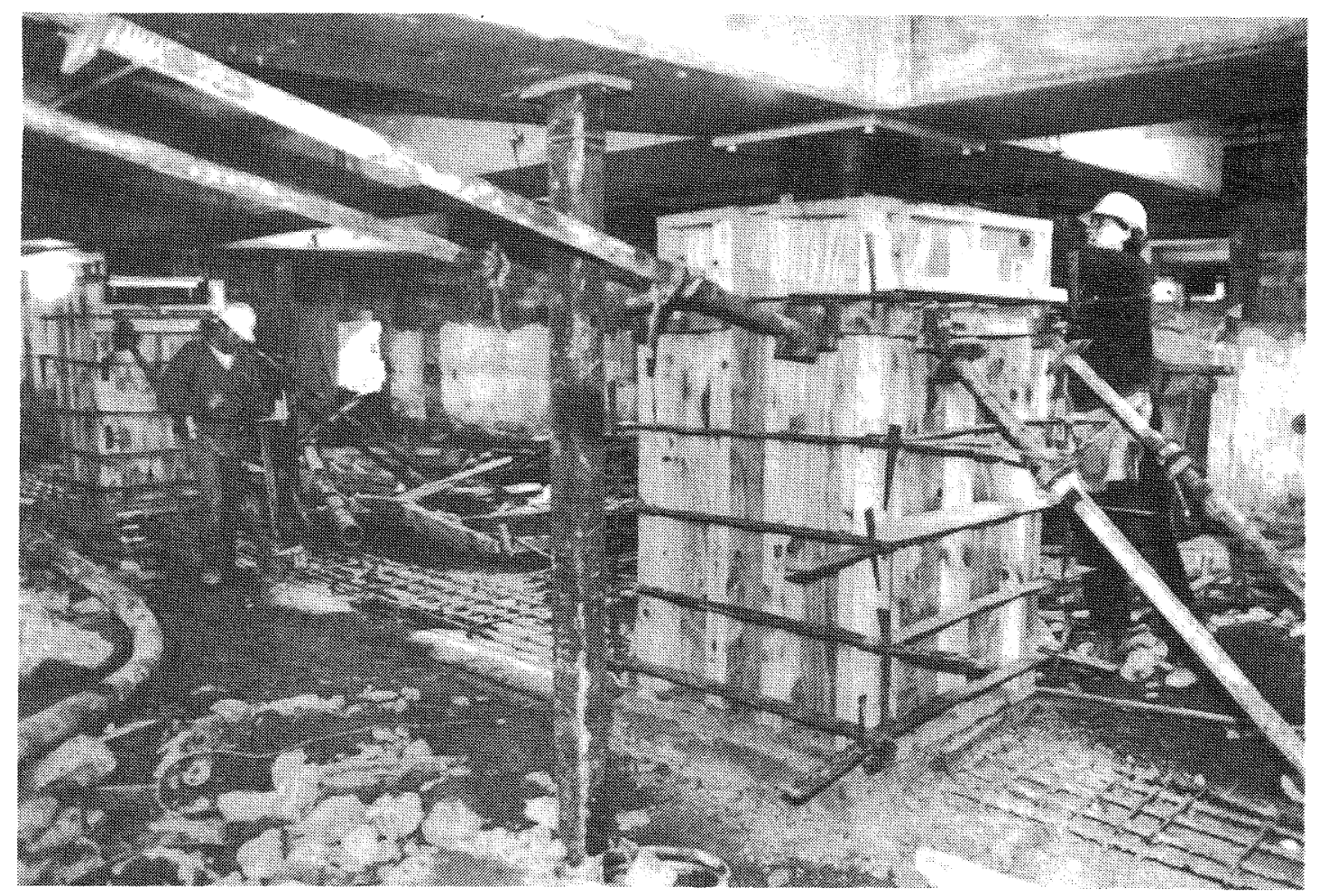

FIGURE 7 Lead-rubber bearings being retrofitted under New Zealand Parliament Building

Estimates for damage costs are included in Figure 8(b). These results illustrate the significant reduction to damage costs in the case of the isolated Museum. The estimated period of the isolated structure is high at 2.5 seconds to overcome problems with the site, an area which has been 'reclaimed' from the shoreline.

Results of a dynamic nonlinear analysis for 'El Centro (frequency scaled)', 'El Centro SHAKE Output', Tabas SHAKE Output' and 'Llolleo SHAKE Output' are at the isolator level $247,209,258$, and $241 \mathrm{~mm}$ for a 250 year earthquake, while for the 2000 year return period the vector displacements are $484,452,516$, and $421 \mathrm{~mm}$.

To ensure adequate performance of the isolation system all of the lead-rubber bearings have been tested by our Institute. Figure 11 is an example of the force-displacement loop for a bearing designed for a nominal shear force of $1 \mathrm{MN}$ and a stroke of $+/-130 \mathrm{~mm}$, manufactured in New Zealand by Skellerup Industries. For the prototype lead-rubber bearings the test vertical loads are as high as $13.4 \mathrm{MN}$ (1340 tonnes) and displacements up to $487 \mathrm{~mm}$. The test rig for these tests is shown in Figure 10.

\section{SEISMIC ISOLATION OF SPECIAL STRUCTURES}

Seismic problems arise with light-weight, delicate or potentially hazardous structures and sub-structures such as life-support equipment in hospitals, important works of art, equipment sensitive to vibration, and the radioactive components and associated support systems of nuclear reactors. An example of such a structure, where seismic installation was installed because the costs of the contents far exceeded that of the building, is the
Evans and Sutherland Building in Utah, USA, which manufactures computerised flight simulator equipment. Another example is the Mark II Detector for the Linear Collider at Stanford University, California.

In New Zealand, this problem was solved for two very different cases, namely the seismic protection of a brittle cast-iron printing press in Petone, and that of $\mathrm{AC}$ capacitor banks at Haywards Substation (electrical). Both these locations are close to the Wellington fault and in the sphere of influence of other major faults.

\subsection{Haywards Substation}

Electricity suppliers in New Zealand have started a process of selective retrofitting of seismic isolation to key items of highly vulnerable substation equipment. A recent example of this retrofitting is provided by the isolation of capacitor stacks at the Haywards Substation, which is a major substation $20 \mathrm{~km}$ north of Wellington. A typical capacitor stack consisted of a group of capacitors with brittle ceramic insulators, mounted within a cross-braced steel cage measuring $9 \mathrm{~m}$ in length, $6 \mathrm{~m}$ in height, and $3.6 \mathrm{~m}$ in width. It weighed 26 tonnes and was supported on 8 ceramic insulators each $1.5 \mathrm{~m}$ high.

Seismic isolation was achieved by raising the capacitor stack and its insulators approximately $1 \mathrm{~m}$ off the ground and inserting a horizontal steel frame that was supported on six segmented, laminated steel-rubber bearings. The relatively low mass of the capacitor stacks required a very low shear stiffness for the bearings, which therefore had to be made from rubber-encased steel plates separated from one another by small pads of rubber in order to give adequate stability 

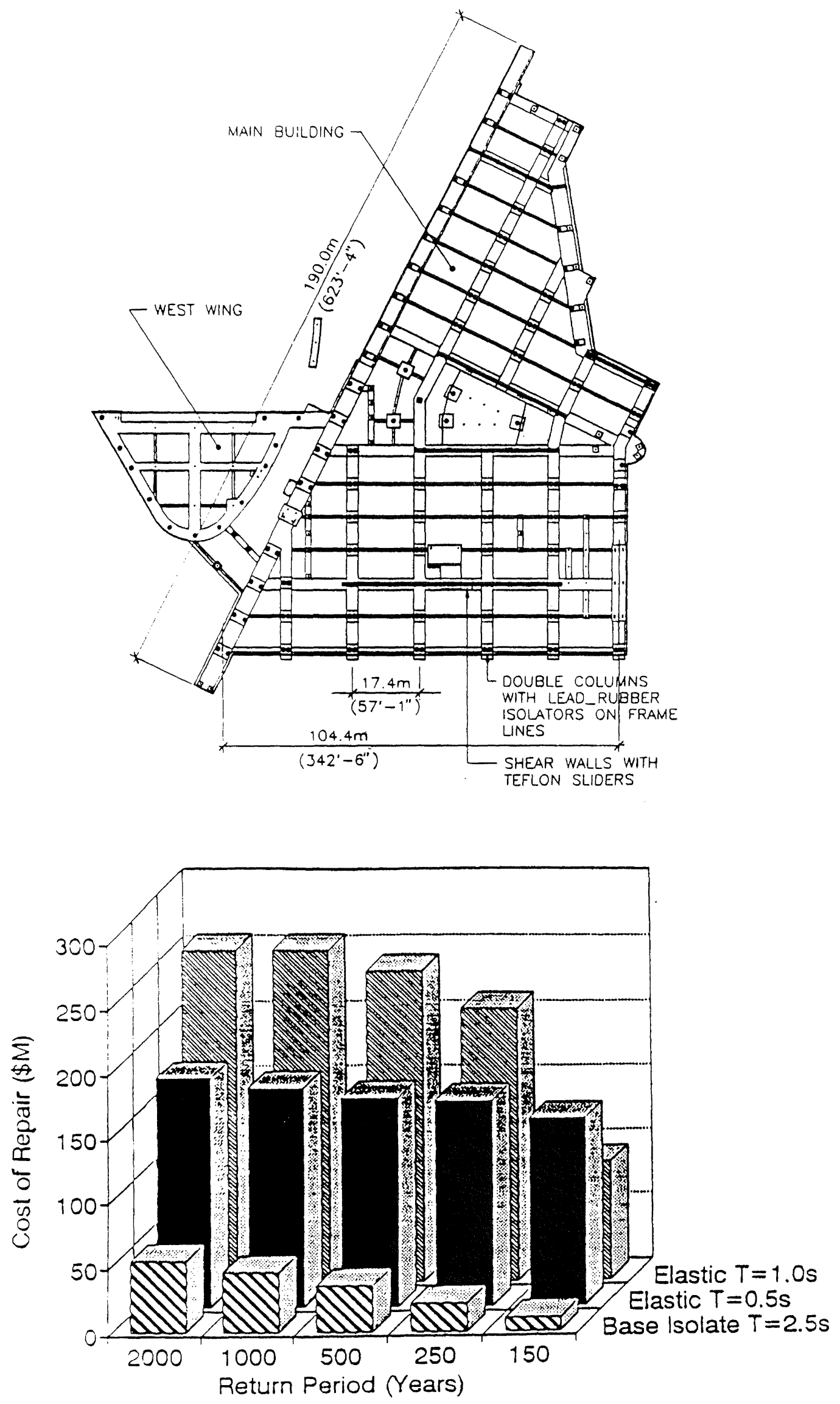

FIGURE 8 (top) Plan of foundations of Museum of New Zealand, (b) results of feasibility study on damage costs 
Damping was provided by two steel taper-beam dampers which were connected between the steel frame and the ground at each end of the capacitor stack. Specifications for the dampers were derived from dynamic analyses of the isolated structure. The main ones were: nominal damping force: $10 \mathrm{kN}$; displacement capacity: $\pm 200 \mathrm{~mm}$; lifetime: $>70$ cycles at full displacement; and directionality: omni-directional in horizontal plane. The total damping force (yield force) required for each capacitor stack was approximately $10 \%$ of the structural weight. This was higher than normally used in seismic-isolation and was a consequence of the severe seismic design requirements.

A cylindrical type of taper-beam damper seemed most appropriate given the small damping force and the need for omni-directionality. The design procedure was as described by Tyler [1978a,b], and resulted in a $500 \mathrm{~mm}$ long device of base diameter $45 \mathrm{~mm}$, tapered over the lower two-thirds of its length to a diameter of $31.5 \mathrm{~mm}$. The peak strain level in the steel beam at full displacement was estimated to be 0.03 which implied a cycling lifetime in excess of 100 cycles [1978a].

This damper had a much smaller load capacity than those previously used in New Zealand and so cyclic load testing was required to firmly establish the mechanical performance characteristics. Two dampers were tested and both met the specifications listed above.

\subsection{Printing press, Wellington Newspapers Ltd}

The printing press was made principally of cast-iron and was equivalent vertically to a four storey building [Dowrick et al, 1991]. It was located in a building made principally of reinforced concrete with a structural steel roof. To provide maximum protection from earthquakes the building was especially stiffened up to a height of $8.6 \mathrm{~m}$ and was linked to the press with horizontal struts at heights of 4 and $8.6 \mathrm{~m}$
(Figure 9). Seismic isolation was achieved by providing leadrubber bearings at the base.

In order to achieve the design displacement of $\pm 250 \mathrm{~mm}$ and damping force of 5 percent of structural loads, it was necessary to use bearings that were $609 \mathrm{~mm}$ square in plan, $460 \mathrm{~mm}$ high and fitted with $100 \mathrm{~mm}$ diameter lead plugs. The bearing height was about 50 percent greater than for any previously tested leadrubber bearings, and so prototype testing of a pair of bearings was carried out to confirm their properties [Cousins et al, 1991].

The hysteresis loops were similar in general form to those obtained previously for smaller lead-rubber bearings [Robinson, 1982; Robinson and Cousins, 1988], although there was a tendency towards increased damping force as either the applied displacement or the axial load on the bearing were increased. The post-yield shear stiffness of a single bearing under large displacements was estimated to be $0.9 \mathrm{kN} / \mathrm{mm}$ which equals the shear stiffness of a similar laminated steel-rubber bearing without a lead core. The damping force for displacement amplitudes greater than $150 \mathrm{~mm}$ and axial loads of 1.0 and 2.6 MN was equivalent to a yield strength in shear for the lead plug of $10.2-11.5 \mathrm{MPa}$, which compares well with $10.5 \mathrm{MPa}$, the yield strength in shear for high purity lead.

\section{SEISMIC ISOLATION RESEARCH IN NEW ZEALAND}

The Engineering Schools at the Universities of Auckland and Canterbury (Christchurch) undertake research in structures with both universities studying Engineering Seismology and Seismic Isolation. Examples of the capacities of test equipment at the University of Auckland are: $350 \mathrm{kN}( \pm 100 \mathrm{~mm})$ dynamic, 500 $\mathrm{kN}( \pm 200 \mathrm{~mm})$ or $200 \mathrm{KN}( \pm 100 \mathrm{~mm})$ static; Canterbury 10

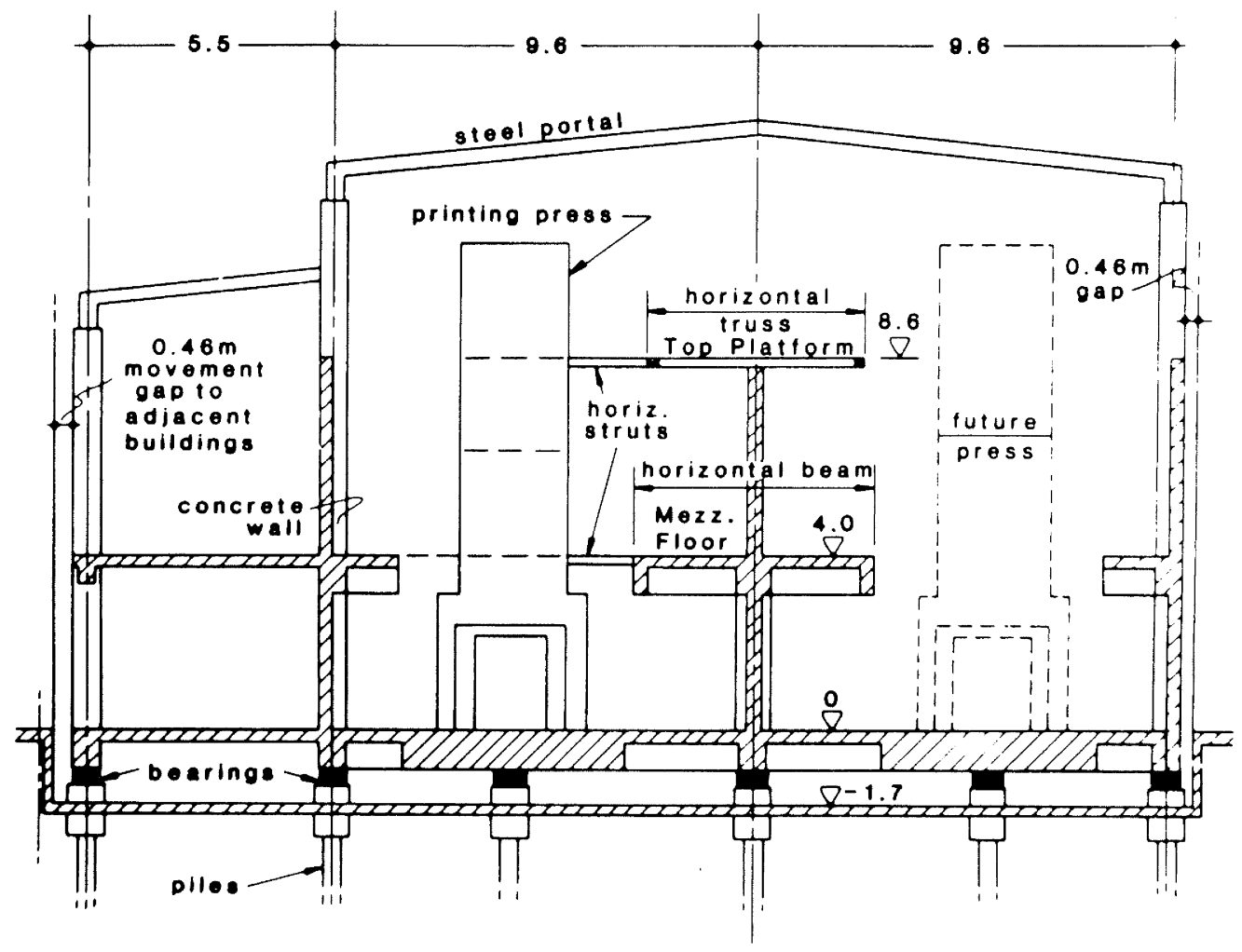

FIGURE 9 End elevation of Press Hall for Wellington Newspapers 


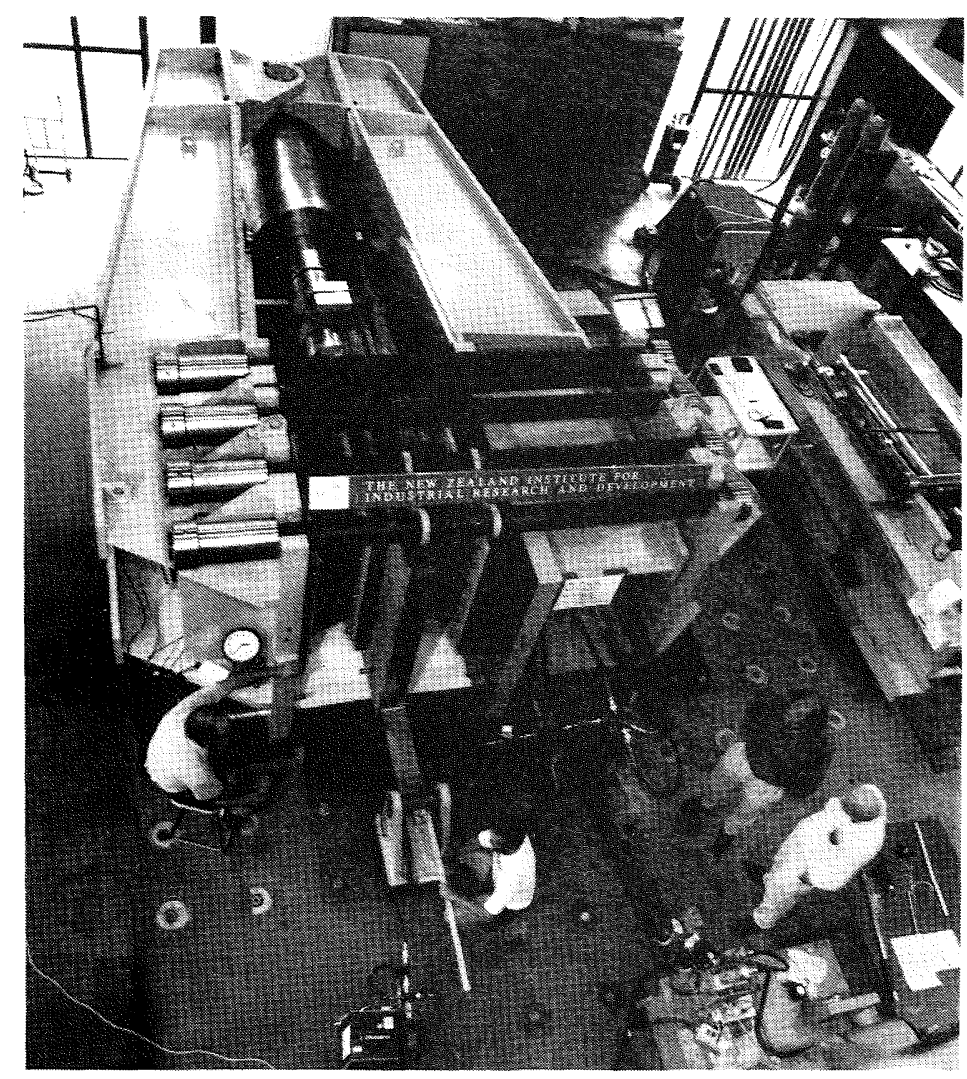

FIGURE 10 The 7.5 MN (shear force) test rig at the NZ Institute for Industrial Research and Development

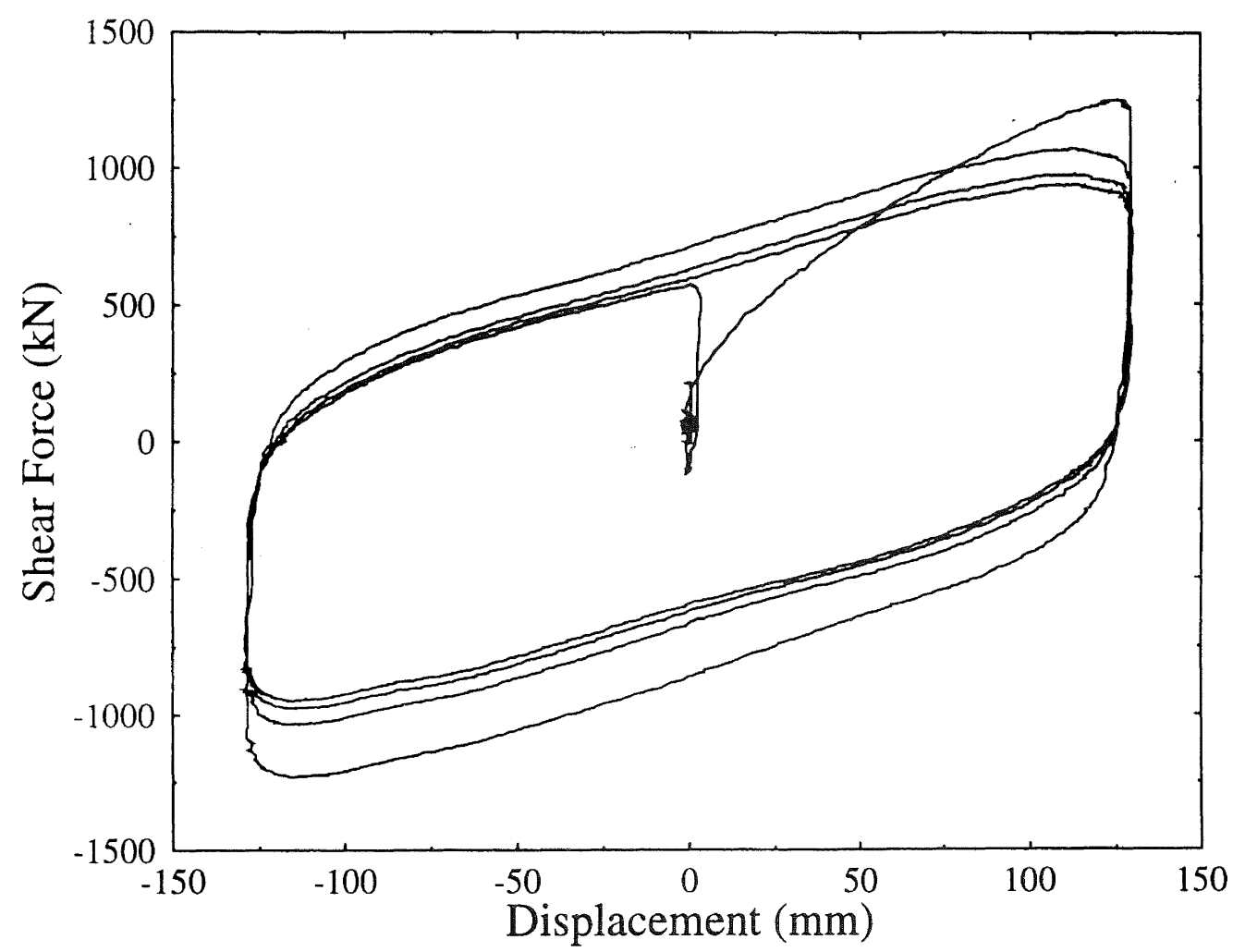

FIGURE 11 Hysteresis loops for the Museum of NZ lead-rubber bearings 
MN ( $\pm 150 \mathrm{~mm})$ dynamic; and both Universities have various capacity static jacks. Canterbury has a world-wide reputation for its research on reinforced concrete structures.

The Engineering Seismology section of the NZ Geological Institute is involved in recording strong earthquakes, structural dynamics and is involved, with the NZ Institute for Industrial Research, in further development of the technology of damping devices.

Civil Engineering consultants such as the Holmes Group and Works (test capacity to $2 \mathrm{MN}(+150 \mathrm{~mm})$ ) have in-house studies which they often publish [Boardman and Kelly, 1993].

At our company, our dynamic equipment includes a testing rig built to test all of the bearings for isolating Parliament. This rig is capable of providing a shear force of $1 \mathrm{MN}(+500 \mathrm{~mm})$ with vertical loads of up to $5 \mathrm{MN}$ compression and $1 \mathrm{MN}$ tension. Our latest test rig, completed in October 1993, has a shear capacity of $7.5 \mathrm{MN}$ (750 tonnes, $\pm 500 \mathrm{~mm}$ ) and can provide vertical loads of $40 \mathrm{MN}$ (4000 tonnes) compression and $20 \mathrm{MN}$ tension (Figure 10). We have tested all of the Museum of New Zealand lead-rubber bearings in this rig. A typical force displacement hysteresis loop for a lead-rubber bearing designed for a vertical load of 7.3 MN is shown in Figure 11.

\section{CONCLUSIONS}

We in our laboratory (PEL (DSIR), than Industrial Research Limited and now Pel) have been privileged over the last 25 years in being actively involved in an exciting field: seismic isolation. During this time the field has moved from a theoretical concept, through experimental studies, to the development of devices and prototypes, and finally to extensive use in applications characterised by remarkably rapid technology transfer both in New Zealand and overseas.

The New Zealand experience in seismic isolation can be summarised as follows:

- Bridges: Of the 49 seismically isolated bridges in New Zealand, 40 use the lead-rubber bearing, 2 use lead extrusion dampers, one uses a combination of these and 6 use steel dampers. Yield force to weight ratio $\sim 10 \%$ in the transverse direction and $\sim 10$ to $20 \%$ for the longitudinal direction.

- Buildings: Two methods have been used for seismically isolating buildings. For cases where there is a firm foundation the lead-rubber bearing has been used (William Clayton Building and the NZ Parliamentary Building and Library), while for cases where the sub-soil is poor or reclaimed a system based on the lead-rubber bearing (Museum of New Zealand) or flexible piles with sleeves has been used, with either steel dampers (Union House, Auckland) or lead-extrusion dampers (Wellington Central Police Station) to absorb the energy. Yield force to weight ratio $\sim 3.5$ to $5 \%$ with isolated periods of 2.5 to 3 seconds.

- Special structures: For fragile or brittle structures, the following methods have been used: lead-rubber bearing (Printing Press), segmented elastomeric bearing with steel damper (Haywards Substation), and rocking with steel dampers (chimney in Christchurch). Yield force to weight ratio $\sim 5$ to $10 \%$ and isolated periods of $\sim 2$ to 3 seconds.
- Future: We believe the technology of seismic isolation has now reached a mature stage where it is to be strongly recommended as an option to be included in the design of structures or buildings in regions of seismic risk, particularly where the building or its contents are of significant value to the community.

The new surgical ward at Hutt Hospital near Wellington is being built on lead-rubber bearings.

- Added Damping: At present our investigations include 'added damping' to reduce the internal displacements of tall buildings during high winds and earthquakes. These 'added' or 'plastic' dampers, which operate at displacements from one micrometer to tens of millimetres, and will, when strategically placed, increase the total damping of the building significantly

\section{ACKNOWLEDGEMENTS}

The staff of the Physics and Engineering Laboratory of DSIR up to July 1992 when the Department of Scientific and Industrial Research (DSIR) was restructured into ten research institutes.

\section{REFERENCES}

Boardman,P.R. and T.P. Kelly, 1993. Seismic design of the Museum of New Zealand, Technical Conference. New Zealand National Society for Earthquake Engineering, p. 80 .

Charleson, A.W., P.D. Wright and R.I. Skinner, 1987. Wellington Central police Station, Base isolation of an essential facility, Proc. Pacific Conference on Earthquake Engineering, New Zealand Vol.2:377-388. New Zealand National Society for Earthquake Engineering.

Cousins, W.J., W.H. Robinson and G.H. McVerry. 1991 Recent developments in devices for seismic isolation. Proc. Pacific Conference on Earthquake Engineering. New Zealand Vol 2:221-232. New Zealand National Society for Earthquake Engineering.

Dowrick, D.J., J. Babor, W.J. Cousins and R.I. Skinner. 1991 Seismic isolation of a printing press in Wellington, Vew Zealand, Proc. Pacific Conference on Earthquake Engineering. New Zealand. Vol 3:35-44. New Zealand National Society for Earthquake Engineering

Poole,R.A. and J.E. Clendon, 1992. New Zealand Parliament Buildings: Seismic protection by base isolation, Bulletin of the New Zealand National Society for Earthquake Engineering, 25(3):147-160.

Robinson, W.H. 1982. Lead-rubber hysteretic bearings suitable for protecting structures during earthquakes. Earthquake Engineering and Structural Dynamics, 10(4):593-604

Robinson,W.H. and W.J. Cousins. 1988. Lead dampers for base isolation, Proc. Ninth World Conference on Earthquake Engineering, Tokyo-Kyoto. Japan Vol III: $427-432$ 
Robinson, W.H. and L.R. Greenbank, 1976. An extrusion energy absorber suitable for the protection of structures during an earthquake, Earthquake Engineering and Structural Dynamics, 4(3):251-259.

Skinner, R.I., W.H. Robinson and G. McVerry, 1993. An introduction to seismic isolation, Wiley, Chichester, England.

Tyler, R.G. 1978a. A tenacious base isolation system using round steel bars, Bulletin of the New Zealand National Society for Earthquake Engineering, 11(4):273-281.

Tyler, R.G. 1978b. Tapered steel energy dissipators for earthquake resistant structures, Bulletin of the New Zealand National Society for Earthquake Engineering, 11(4):282-294.

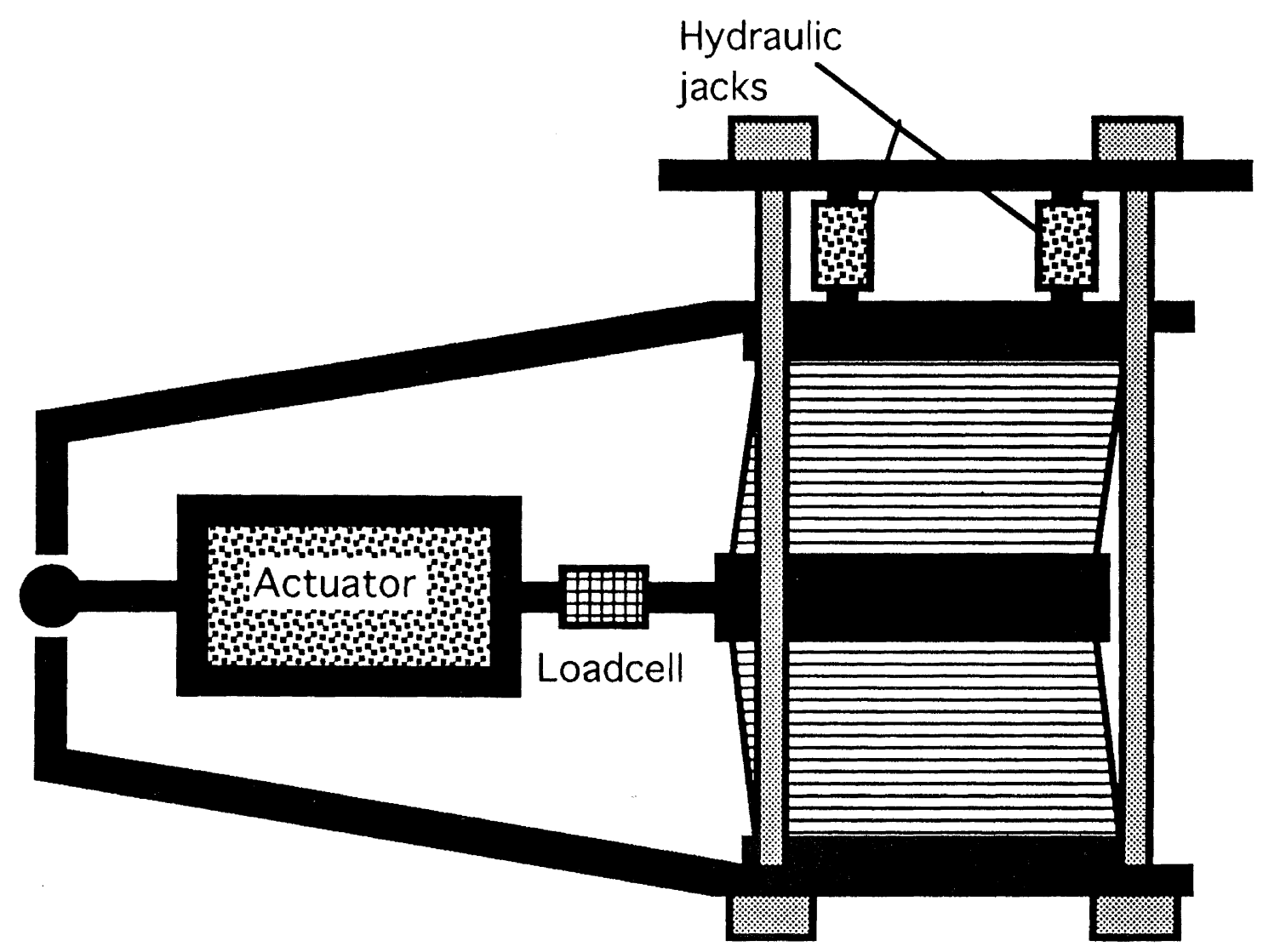

FIGURE 12 Diagram of the dynamic rig for testing bearings 